\title{
ENHANCING EMPLOYEES PERFORMANCE THROUGH A WORK ETHIC WITH ISLAMIC SPIRITUAL LEADERSHIP BASED, HUMAN RELATION, ORGANIZATIONAL SUPPORT, WORKPLACE SPIRITUALITY, AND ORGANIZATIONAL COMMITMENT
}

\author{
Elviera Rosa Pangestika*
}

* Affiliation:

Fakultas Ekonomi Unissula Semarang Email:

elvierarosapangestika@ gmail.com

\begin{abstract}
:
This study aims to test and analyze employee performance improvement through work ethos with the influence of spiritual leadership of Islam, human relations, organizational support, workplace spirituality, organizational commitment. Population in this research is employees of Islamic Hospital Nahdlatul Ulama Demak which amounted to 68 people with respondent retrieval through purposive sampling technique with census method. Analyzer used is path analysis. From the result of data test by using SPSS, it is found that spiritual leadership of Islam, human relation, organizational support, workplace spirituality, organizational commitment have positive and significant effect to work ethic, meaning if spiritual leadership of Islam, human relation, organizational support, workplace spirituality, then it will increase the work ethic. Spiritual leadership and organizational commitment have a positive and significant impact on employee performance, meaning that if spiritual leadership and organizational commitment increase then it will improve employee performance. The work ethic variables are evident as intervening variables with the mediation of spiritual leadership of Islam, human relations, organizational support, workplace spirituality, organizational commitment to employee performance.

Keywords: Spiritual leadership of Islam, human relations, organizational support, workplace spirituality, organizational commitment, work ethic, employee performance.
\end{abstract}

\section{INTRODUCTION}

Work ethic is a whole consisting of personality, confidence, to bring about the achievement of optimal results (Tasmara, 2002). While the performance of the employees is a thing that is urgent, because the progress of the company can be good depending on the employee's 
performance for a company cannot be separated from the performance of employees. Hasibuan (2009), explaining that the performance is the result of work accomplished person in carrying out the duties charged to him based on the skills, experience, seriousness as well as time. The target must be able to work achieved HUMAN RESOURCES to achieve planned company since the beginning, according to (Nawawi, 2006). Performance is said to be high if a target work can be completed in a timely manner or not speeding time limits provided.

So the performance of the employees can say is an outcome that is created from the work done by human resources with a view to achieving the desired target. The research results is work ethic a positive effect on the performance of the employee, the meaning is if increasing work ethic then this will result in increased employee performance. While the work ethic itself can be formed with a variety of strategies for example is in the style of spiritual leadership, as for spiritual leadership according to (Tobroni, 2005) is a leadership that brings the dimension of worldliness to the dimensions divinity, God is the true leaders inspire, influence, serve and moves the conscience of his slaves with a very wise through ethical approach and example.

The existence of this spiritual leadership would create a good work ethic because HR felt sure that leaders who adhered in the works are a good leader. Human relation is also a way to create a good work ethic because human relation is intertwined relationships between employees, very good situation and physical conditions of the work environment itself, security and safety is good for employees, the social working environment, attention to the needs of the physical as well as spiritual, self esteem in the work environment, leadership, the granting of incentives to employees (Sinamo, 2005) .

According to (Yoon and Lim, 1999) organizational support is support provided to company employees so that it nurtures the motivation to help each other in any work activity in the company. Good support from this company will be able to create a good work ethic, with a high work ethic of employees within an organization can be affected by good support in the social scale, as well as in the Organization itself either from boss or co-workers.

The next strategy that can create a good work ethic is Workplace Spirituality according to (Milliman, et al (2003) suggests that workplace spirituality is about expressing a desire to find meaning and purpose in life and it is a process switch on a unit set the values held by a very private person. Integrating spirituality in the workplace will make employees feel the meaning and feeling of aims in life.

Organizational commitment is a commitment shared by human resources at the company, a member of an organization that committed to the organization might just develop a pattern of more positive viewpoint toward the Organization and happily without coercion removing the extra energy in the interest of the Organization (and Anik Arifuddin, 2003). It shows that organizational commitment means more than just a passive loyalty, but involves an active relationship and the desire of employees to contribute the means at the Organization.

Human resource has a high commitment to the company will work seriously and prioritise the success of companies reach the target due to Human resource already feel that the company is a part of him so Human resource will feel glad if the company is able to achieve the objectives and Human resource will feel sad if the company is not able to achieve the goal. If the Human resource already committed to this company will benefit because the company 
Human resource will have a good work ethic so that will add to the company's profits because of the performance given by Human resource.

Companies need to have the human resources performance of quality, creating a quality Employee Performance will benefit the company as it will make it easier for the company to achieve its objectives, this good performance also needs to be owned by Nahdlatul Ulama Islam hospital Demak, where Muslim Nahdlatul Ulama Hospital Demak it was the hospital that is the city of Demak which is a business that moves in the field of health services. Facilities services provided include the emergency unit 24 hours, inpatient, outpatient, 24-hour delivery, practice specialist clinics, laboratories, x-rays, and ambulance. In terms of the amount of the decrease in the number of patients also occur during the last 3 years is described as follows :

Table 1.1

\section{The Number Of Hospital Patients Demak Nahdlatul Ulama Islam Year 2014-2016}

\begin{tabular}{|l|l|l|}
\hline Year & Patients & Percentage \\
\hline 2014 & 11.172 & - \\
\hline 2015 & 10.543 & $-6 \%$ \\
\hline 2016 & 10.104 & $-4 \%$ \\
\hline
\end{tabular}

From the table above seen that hospital patients Nahdlatul Ulama Islam Demak has decreased the number of patients, the number of patients in the year 2014 the year 2015 totaled 11,172 , the number of patients as much as 10,543-decreased by $6 \%$ and in the year 2016 patients 10,104 declines amounted to-4\%. The decline in the number of these patients need is questionable considering the competition between hospitals is very strong.

\section{LITERATURE REVIEW Employee Performance}

The performance is a result of work from both the quality and quantity of which is achieved by a person in carrying out its work employees in accordance with the responsibilities given by the employees. The performance is a form of work obtained someone in doing the duties charged to him based on the skills, experience, and commitment as well as time (Hasibuan, 2005).

Indicators to measure Performance according to the (Masud, 2014):

1. Capable of increasing the target's work.

2. Being able to finish the work on time.

3. Being able to finish the job with a neat.

4. Able to minimize job errors.

\section{Islamic Spiritual Leadership}

Spiritual leadership is a creation of values, attitude, the behavior is needed to motivate me and others at intrinsic motivation so as to achieve a sense of spiritual survival through calling/meaning and membership. Spiritual leadership that exists on one's self will encourage a high sense of commitment. 
Indicators of spiritual leadership of Islam expressed by (Bedjo Santoso, 2009):

1. Amanah.

2. Hard work, intelligent, and sincere.

3. Role model and conscience.

4. Blend of faith and compassion.

5. Spread the virtues.

6. Consolidated idiil with the pure intention.

7. Develop brotherhood and collaboration and synergy.

8. Building integrity.

9. Evokes gratitude and patience.

\section{human Relation}

Human Relations (human relations) was the leader of an organization to communicate with employees humanely (human communication) to motivate them and working together, so it will get a good result for them working with a quiet heart.

Indicators of human relation which was adopted by the (Istijanto, 2010):

1. Relationship with colleagues.

2. Relationship with the boss.

3. Client relationships.

4. Relationship with the community.

\section{Organizational Support}

Organizational support is support provided to company employees so it will be created a motivation to help each other in any work activity within the company (Yoon dan Lim, 1999). Indicators support the organization according to (Rhodes \& Eisenberg, 2002) are:

1. Justice.

2. Appreciation from organization.

3. Work condition.

\section{Workplace Spirituality}

Workplace spirituality is also related to the desire of employees to obtain the results of the work they do, the desire to enhance the spirit of the place of work is the process of looking for something that is far beyond than just revenue and performance (Ashmos \& Duchon, 2000).

Indicators of workplace spirituality according to (Ashmos dan Duchon, 2000) :

1. Inner life.

2. Meaningful Job.

3. Be the part of community.

\section{Organizational Commitment}

Organizational commitment is a member of an organization that committed to the organization can develop a more positive view of the Organization and be happy without spending extra energy for the benefit of the Organization (Anik dan Arifuddin, 2003). 
Indicators to measure organizational commitment according to (Arfan Ikhsan, 2010):

1. Effective Commitment.

2. Sustainable Commitment.

3. Normative Commitment.

\section{Work Ethic}

Etos kerja merupakan suatu totalitas kepribadian dari individu serta cara individu mengekspresikan, memandang, meyakini dan memberikan makna terhadap suatu yang mendorong individu untuk bertindak dan meraih hasil yang optimal (high performance) (Tasmara, 2002).

Menurut (Subekti, 2001) indikator untuk mengukur etos kerja adalah :

1. Kerja sebagai suatu hal yang amat luhur.

2. Ketekunan dalam bekerja.

3. Kerja dilakukan sebagai bentuk ibadah.

\section{The influence of Spiritual Leadership of Islam against the work ethic}

Fry (2003) stated that the spiritual leadership is the formation of values, attitude, behavior is needed to motivate self and others are intrinsic motivation so that reaching for the spiritual sense of survival through calling/ meaning and membership. Work ethic is a totality of the personality of the individual and the individual's way of expressing, looked at, believe and give meaning to a that encourages individuals to act and achieve optimal results (high performance) (Tasmara, 2002)

The results of research conducted by (Haerudin, Bedjo Susanto, 2016) the results of this research show that there is a connection between Islamic work ethic and work engagement, between the Islamic work ethic, organizational culture, spiritual leadership, and commitment organizational measures. Based on the evidence presented above, the research hypothesis as follows:

H1: spiritual Leadership of Islam is a positive and significant effect against the work ethic

\section{The influence of Human Relation towards work ethic}

Human relation is human relationships which are here the nature of their relationship is not like ordinary people communicate, not only is the delivery of a message by a person to another person, but the relationship between the people who communicate it contains elements of a very profound psychological abuse (Onong, 1992).

Work ethic is a set of positive behaviors that are rooted in the fundamental belief that accompanied a total commitment to the paradigm of work integral (Sinamo, 2005). In a study conducted by (Hapsari, et al. 2015) in her research results that human relation has a positive influence against the work ethic. That means the higher the human relation will be increasingly higher work ethic. Therefore, in this study the second hypothesis put forward, namely:

$\mathrm{H} 2$ : Human relation positive and significant effect against the work ethic. 


\section{The influence of Organizational Support against the work ethic}

Organizational support is support given the company towards its employees so that nurtures the motivation of employees to help each other in any work activity within the company (Yoon and Lim, 1999). According to (Octarina, 2013) that work ethic is the totality of the personality and way of self expressing, looking, assuring, and gives meaning to something.

Research conducted by Hapsari et al (2015) reveals that the existence of a positive and significant influence between the organizational support against the work ethic. Therefore, this study proposed the hypothesis to the three IE:

H3: organizational support is a positive and significant effect against the work ethic

\section{The influence of Workplace Spirituality against the work ethic}

Workplace Islamic spirituality that is the awareness of the people who have inner lives that are grown and grown by meaningful work and takes place in the context of the community. Employees living with himself as spiritual beings. Work ethic is a totality of the personality of the individual and the individual's way of expressing, looked at, believe and give meaning to a that encourages individuals to act and achieve optimal results (high performance) (Tasmara, 2002).

Based on the results of research by (Hapsari et al, 2015) in research results that workplace spirituality has a positive and significant influence against the work ethic. That means the higher the workplace spirituality will be increasingly higher work ethic. Thus the proposed fourth hypothesis is as followst :

H4: Workplace spirituality positive and significant effect against the work ethic.

\section{The influence of Organizational Commitment towards workethic}

Organizational commitment is a member organization which committed to the organization might just develop a pattern of more positive viewpoint toward the Organization and happily without coercion issued extra energy for the benefit of Organization (Anik and Arifuddin, 2003). Work ethic is a set of positive behaviors that are rooted in the fundamental belief that accompanied total commitment on an integral work paradigm (Sinamo, 2005).

Research conducted by (Haerudin Bedjo \& Sasanto, 2016) in her research to find the results that have a positive influence on organizational commitment and significantly to the work ethic. Which means the better the organizational commitment it will also better work ethic. Thus in this study proposed the fifth hypothesis i.e.:

H5 : Organizational commitment to a positive and significant effect on the work ethic.

\section{Influence on performance of employee work ethic}

According to (Cctarina, 2013) that work ethic is the totality of the personality and way of expressing himself, looking, certain, and gives meaning to something. Work ethic can be formed when an employee has a desire to be able to do a job with satisfactory results or maximum results. Performance is the result of work in the quality and quantity achieved by employees in carrying out its function of a person in accordance with the responsibilities given to the employees. Employee performance is the result of work accomplished person in carrying out the duties charged to him based on the skills, experience, seriousness, as well as time ( Hasibuan, 2009). 
Research by (Hapsari et al, 2015) in her research results that work ethic has a positive and significant influence on the performance of employees. Which means the better the work ethic will be the better performance of employees. Thus in this research proposed sixth i.e.:

H6: work ethic is a positive and significant effect on the performance of employees.

\section{The spiritual leadership of islam's influence on performance of employees}

FRY (2003) revealed that the spiritual leadership is the formation of values, attitude, the behavior is needed to self-motivation and others are intrinsic motivation so that reaching for the spiritual sense of survival through calling/ meaning and membership. According to (Mangkunegara, 2005) performance is the comparison of the results achieved with the role as well as the Labor Union of the time. Besides the performance associated with employees is the result of work in the quality and quantity is achieved by an employee in performing its duties in accordance with the responsibility which is given.

Research conducted by (Tanuwijaya, 2015) in her research to get the result that there is a positive and significant influence between the spiritual leadership against the current performance. That means increasing spiritual leadership then performance will increase as well. Therefore in this study proposed the hypothesis that:

H7 : The spiritual leadership of Islam is a positive and significant effect on the performance of employees

\section{The influence of Organizational Commitment on the performance of employees}

Organizational commitment is a form in which a particular organization favoring employees as well as the goals and desires to retain membership in the Organization (Robbins and Judge, 2008). According to (Maryanto, 2000) performance is the result of work during a certain period in comparison with the various possibilities, e.g. standards, targets/goals or criteria already agreed with. The performance of the individual is the basis of the performance of the organization. This performance assessment (performance appraisal) is essentially a key factor in order to develop an organization effectively and efficiently.

Based on research conducted by (Riane Johnly, et.al., 2015) in her research results that have a positive influence on organizational commitment and significantly to the performance of employees. That means the higher organizational commitment it will be getting highperformance employees. Thus in this study presented the eighth hypothesis i.e.:

H8 : Organizational commitment gives positive impact and significant towards employees performance.

\section{RESEARCH METHOD}

The sample used in this study is the employee remains at the Islamic Hospital Nahdlatul Ulama Demak. In this study used census techniques i.e. all employees who had worked a year, i.e. as many as 68 respondents. 


\section{RESULT AND DISCUSSION Normality}

Normality testing aims to test whether in regression models between the dependent variable independent variable with both have a normal distribution or not. A good regression model is that it has a normal or near-normal distribution, the test results using the Kolmogorov Smirnov one sample.

Based on the research results can be known that value the significance of Kolmogorov Smirnov is $0.084>0.05$. Thus the regression model in this study 1 is normal. Based on Table 4.12 can note that value the significance of Kolmogorov Smirnov is $0.840>0.05$. Thus the regression model in this study is normal.

\section{Heteroscedasticity}

Heteroscedasticity test aims to find out whether in regression models of the residual variance inequality occurred one other observation to observation. Based on Table 4.15, be aware that there is no spread (data standard deviation between the free variables (the Islamic leadership, human relation, organization, workplace support Islamic spirituality, organizational commitment) against variables bound ( work ethic), and do not form a specific pattern, so there happen heteroscedasticity. BerdasarkanTabel 4.16, may note that there is no spread (data standard deviation between the free variables (the Islamic leadership, organizational commitment, and work ethic) against variables bound (performance), and do not form a specific pattern, so there happen heteroscedasticity.

\section{Direct and Indirect Impact}

a. The spiritual leadership of Islam's influence on the performance of employees through work ethic.

The value of direct spiritual leadership of Islam's influence on the performance of employees of 0.295 bigger compared to the indirect influence of 0.093 ( $0.291 \times 0.323$ ), thus in the study of spiritual leadership of Islam direct effect on the performance of employees not through work ethic. Thus the work ethic is not an intervening variable between the spiritual leadership of Islam's influence on the performance of employees. This is because in the works at the hospital, responsibility to the patient is more mainstream in compare personal feelings so that employees will strive to produce a good performance in serving patients with the override work ethic of self-own.

b. The influence of organization on the performance of employees commitment through work ethic.

The value of direct influence on organizational commitment of employees on performance 0.278 bigger compared to the indirect influence of $0.076(0.236 \times 0.323)$, thus in this research directly influential organization commitment on the performance of employees not through work ethic. Thus the work ethic is not an intervening variable between the influence of organization on the performance of employees commitment. This is because in the employees committed to the organizations will work the best for the Organization, resulting in better performance. 
The spiritual leadership of Islam influential positive against the work ethic and performance of employees, it can be interpreted that if the spiritual leadership of Islam in size with an indicator of leadership are the ones who keep the mandate with mutual trust relationships with subordinates, superiors worked hard in their job, have thought that intelligent, sincere leaders are passionate in advancing his company, leader of the example and have a conscience that is leaders who provide example to my subordinates which are good and which are not good.

The leadership has a good faith and compassion means leaders undertook to feel excited when viewing a subordinate and subordinate to unite with one heart, one body, and one spirit, the people who are spreading such policies do not provide criticism that dropped the subordinate and subordinate to help when having problems, the Chairman is the man who always does the consolidation of ideal with good intentions in terms of unifying employees to become a more powerful group, the leader is a person who develops a sense of sisterhood means the leadership of people who are easy to get along and accept criticism and suggestions from subordinates, the leadership is the people who build the integrity that is the leadership that has already made an appointment should be promises kept, the leader is a person who has gratitude and patience means leaders always have a sense of thank you for awarding favors which God gave with the feeling satisfied, then the work ethic and performance of employees will be increased.

Human relation positive effect against the ethos of work, this can be interpreted that if human relation which in size with an indicator able to relate well with coworkers means that employees affected by the community so that communication can occur well, make it easy and the launch of activities to achieve a particular goal. Able to relate well with superiors in the work IE employees can streamline his work. Trying to connect with clients by recognizing clients in advance and communicate with the closer. Trying to connect with the community as always friendly to the community and be polite. Then the work ethic will be increasing. The dominant indicator in explaining human relation is capable to have good relationship with colleagues.

Support the Organization of a positive effect against the ethos of work, this can be interpreted that if support organization in size with the indicators the Organization treats employees fairly IE is not looked at employees with each other. The organization always gives awards to employees of overachievers and do a good job. Working conditions in the organization feel safe and comfortable i.e. where employees are highly valued and feel no disturbance that threatened employees. Then the work ethic will be increasing.

Workplace spirituality positive effect against the ethos of work, this can be interpreted that if workplace spirituality which in size with an indicator of job creating a feeling of happiness and feel hopeful life means that organizations must make the hearts of employees happy so will work in accordance with the results of hope. Feel it creates excitement in others and evokes a sense of the passion that is doing a good job and responsibility as well as enjoys the job. Feel part of a community at work means that when you have a community of place of work will also make employees feel more supported in the duties of the job and reduce the burden of the job. Then the work ethic will be increasing.

The Organization's commitment to a positive effect against the work ethic and performance of employees, it can be misconstrued in that if the commitment of the Organization 
in size with the indicator has an effective commitment (emotional/psychological ties to organizations employee) that have a sense of affection taking action against the work occurs because there is a strong emotional bond against the Corporation. Have ongoing commitment (survived because it requires a salary) means that employees will be committed with a supervisor because of high wage labor and employees feel resignation would destroy her family. Has the nature of normative commitment (survive in the organization is the thing to do) means an employee who has a new initiative could probably survive because employees feel left a job with the difficult circumstances and no matter which better. Then the work ethic and performance of employees will be increased.

Etos kerja berpengaruh positif terhadap kinerja karyawan, hal ini dapat di artikan bahwa apabila work ethic in size with indicators that work as a sublime means employees will be remembered by his work. Able to improve the persistence in works that means employees don't easily give up to do a tough job though and trying to better. Believes that work done as a form of community service because employees have a sense of responsibility will work. Then the performance of employees. The dominant indicator in explaining the work ethic was able to improve the persistence in works. This indicates that most respondents had high morale. With diligence in work, they expect what the objectives of the organization can be achieved immediately in accordance with the targeted.

\section{COCNLUSION}

The spiritual leadership of Islam influential positive against the work ethic and performance of employees, it can be interpreted that if the spiritual leadership of Islam in size with an indicator of leadership are the ones that mandate, the leadership are people who work hard, leader is the one who is intelligent, sincere man who is Chairman of the House, the leadership is exemplary and people had a conscience, the leadership has good faith and compassion, the leadership as the spread policy, leadership is the one who always consolidates good intentions by Idil, head is a person who develops a sense of brotherhood, the leadership are the ones that build integrity, leadership is a person who has a sense of gratitude and patience, work ethic and performance then the employees will -increasing.

Human relation positive effect against the ethos of work, this can be interpreted that if human relation which in size with an indicator able to relate well with co-workers, being able to relate well with superiors in working, trying to connect with clients, trying to connect with the community, then the work ethic will be increasing. Support the Organization of a positive effect against the ethos of work, this can be interpreted that if support organization in size with the indicators the Organization treats employees fairly, the organization always rewards, working conditions in the organization feels safe and comfortable, then the work ethic will be increasing.

Workplace spirituality positive effect against the ethos of work, this can be interpreted that if workplace spirituality which in size with an indicator of job creating a feeling of happy and feel hopeful life, felt that work create excitement in others and evoke a sense of spirit, and feel part of a community at work, then the work ethic will be increasing. The Organization's commitment to a positive effect against the work ethic and performance of employees, it can 
be misconstrued in that if the commitment of the Organization in size with the indicator has an effective commitment (emotional/psychological ties to organizations ), have an ongoing commitment (survived because it requires a salary), have the nature of normative commitment (survive in the organization is the thing to do), then the work ethic and performance of employees will be increased. Work ethic a positive effect on the performance of employees, it can be interpreted that if the work ethic in size with indicators that work as a sublime, capable to improve the persistence in works, work believes as a form of devotion, hence increasing employee performance.

\section{REFERENCES}

Anik, S dan Arifuddin. 2003. Analisis Pengaruh Komitmen Organisasi dan Keterlibatan Kerja Terhadap Hubungan Antara Etika Kerja Islam dengan Sikap Perubahan Organisasi. JAAI. Volume 7 No. 2, Hal. 158-182.

Bedjo Santoso. (2009), "Kepemimpinan spiritualitas menjawab keterpurukan bangsa”.

Hasibuan, M. 2005. Manajemen Sumber Daya Manusia. Jakarta: PT Bumi Aksara.

Istijanto. 2010. Riset Manajemen Sumber Daya Manusia. Gramedia Pustaka. Jakarta.

Milliman, John., Czaplewski, Andrew. J and Ferguson, Jeffery. 2003. Workplace Spirituality and Employee Work Attitudes. Journal of Organizational Change ManagementVol.16, No.4, pp 426-447.

Nawawi. 2006. Evaluasi dan manajemen kinerja di lingkungan perusahaan dan industri. Yogyakarta: Gadjah Mada Univercity Press.

Sinamo, Jansen., (2005); Delapan Etos Kerja Profesional; Navigator Anda Menuju Sukses; Grafika Mardi Yuana, Bogor.

Tasmara, T. 2002. Etos Kerja Pribadi Muslim. Yogyakarta: Dana Bhakti Primayasa.

Tobroni, 2005. The Spiritual Leadership, Pengefektifan Organisasi Noble Industry Melalui Prinsip-prinsip Spiritual Etis. Malang: UMM Perss

Yoon, J., \& Lim, J.C. (1999). Organizational support in the workplace: The case of Korean hospital employees. Human Relation, 52, 923-945. 